\title{
ويروس زيكا
}

'فاطمه سلطانزراد'

جكيده

مقدمه: با توجه به شيوع ويروس زيكا در FV كشور دنيا و عوارض خطرناك آن و احتمال بروز آن در ايران، با افزايش دمان

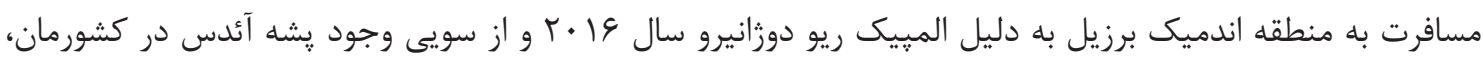

آشنايى و معرفى ويروس زيكا اهميت مى ميابد. هدف: هدف از اين مطالعه آشنايى با ويروس زيكا ميى وياشد.

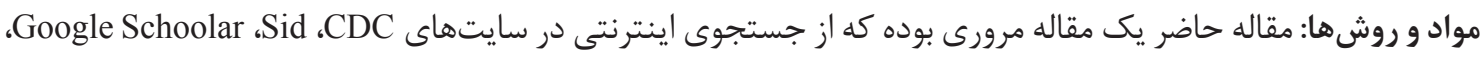
Google يافتها: از آنجايى كه ويروس زيكا از طرف سازمان بهداشت جهانى يك فوريت معرفى شده و وبا توجه به اهميت موضوع، در اين مقاله به آشنايى با ويروس، بيمارى، علائم، تشخيص، درمان، راه كارهاى بِيشخيرى و توصيه براى زنان باردار و

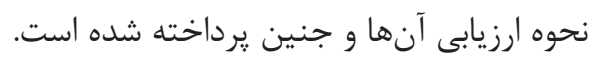
بحث و نتيجهَيرى: با توجه به راههاى انتقال متنوع ويروس زيكا، مناسب بودن كشورمان براى انتشار ويروس، افزايش

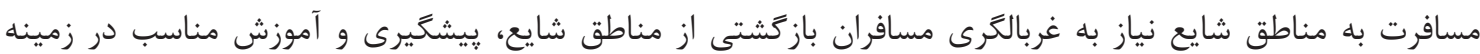

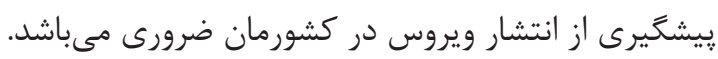

كلمات كليدى: يشه آئدس، يِيشَيرى، ويروس زيكا.

\begin{tabular}{|c|c|c|}
\hline $9 \Delta / \mu / \mu r$ & 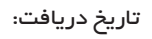 & 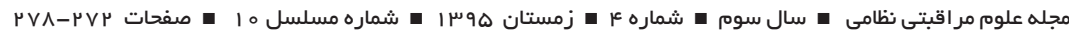 \\
\hline$१ \Delta / \Delta / \mu \mu$ & تاريخ يذيرش: & \\
\hline $9 \Delta / 1 \Gamma / 10$ & 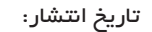 & \\
\hline
\end{tabular}

تائيد شد. براى زيكا واكسنى به بازار ارائه نشده و شيب مبتلايان در

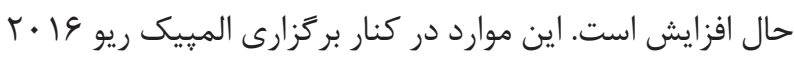

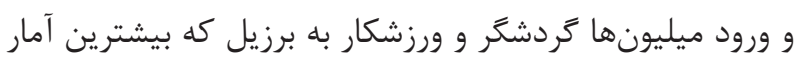

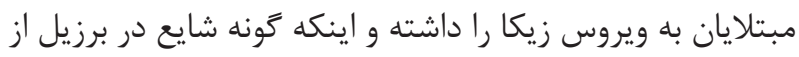
كَونهاى ديكر در كشورهاى ديكر خطرناكتر ظاهر شده است، باعث ايجاد نكرانى ميان مسئولان بهداشتى شده است تا جايى درئ كه اعلام فوريت بهداشتى بينالمللى (PHEIC) Public Health Emergency of International Concern بهداشت World Health Organization (WHO) شده است. بان سمان توجه به حساسيت موضوع ويروس زيكا در ابعاد بينالمللى مقاله حاضر با هدف معرفى ويروس و ابعاد آن شكل خرفت (1).

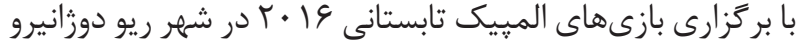

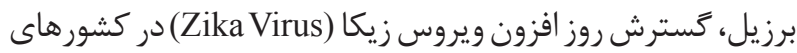
آمريكاى لاتين و به خصوص برزيل به يكى از نغرانىهاى مههم مقامات بهداشتى تبديل شده است و احتمال شيوع اين ويروس در بين ورزشكاران و كردشكران بيشتر از قبل به نظر مىرسد. برآورد

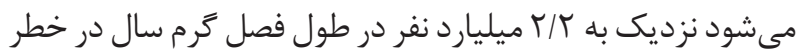
ابتلا به اين ويروس قرار خواهند گرفت. برزيل تاكنون نزديك به به ترديه

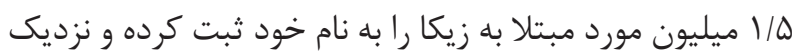
به هزار مورد نوزاد ميكروسفالى در اين كشور به دنيا آمدهاند. جندى بيش ارتباط ويروس زيكا با ميكروسفالى توسط محققان 
مسافر ايرانى يا خارجى آلوده وارد كشور شوند (F).

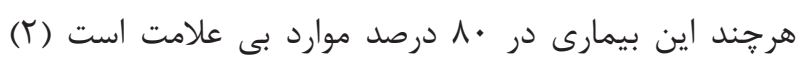

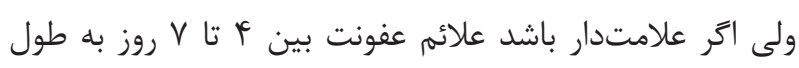
مىانجامد كه خفيف مىباشد و شامل راش، سردرد، درد مفاصل،

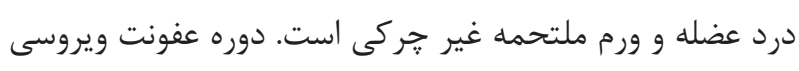

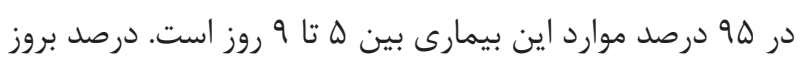

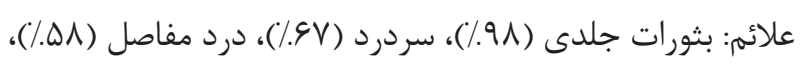

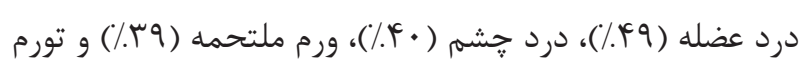

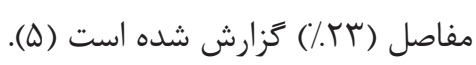

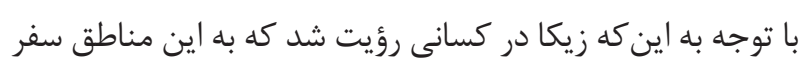

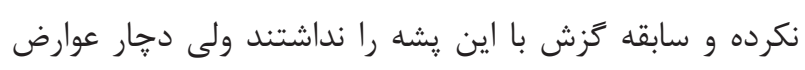

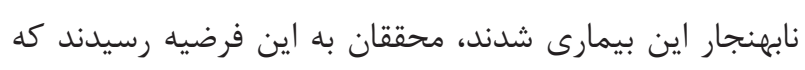

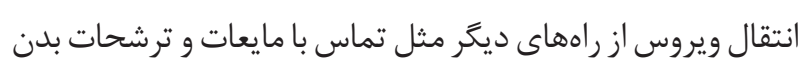
و تماس جنسى محتمل است. به همين دليل از مايعات بدن افراد

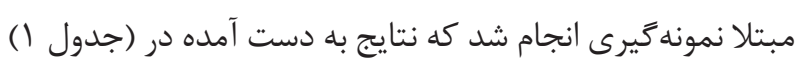

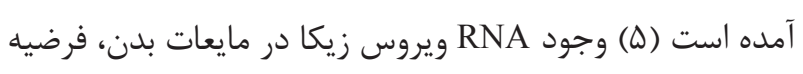
اين محققان را ثابت كند ولى تحقيقات همجنان ادامه دارد.

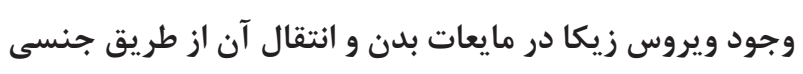
از سه جهت قابل اهميت است:

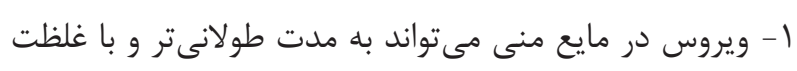

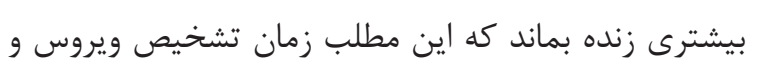

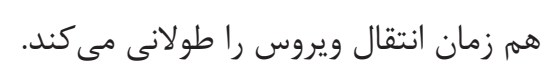

r- ابتلا به ويروس زيكا حتى براى افرادى كه با بشه كزيل نشدهاند، از طريق تماس جنسى با افرادى كه مبتلا هستند

$$
\text { امكانيذير است. }
$$

r- وجود ويروس در مايعات بدن افر اد مبتلا به ويروس زيكا براى إى

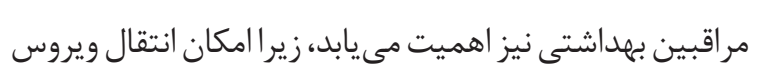

جدول ا- مدت زمان حضور RNA ويروس در مايعات بدن مبتلايان

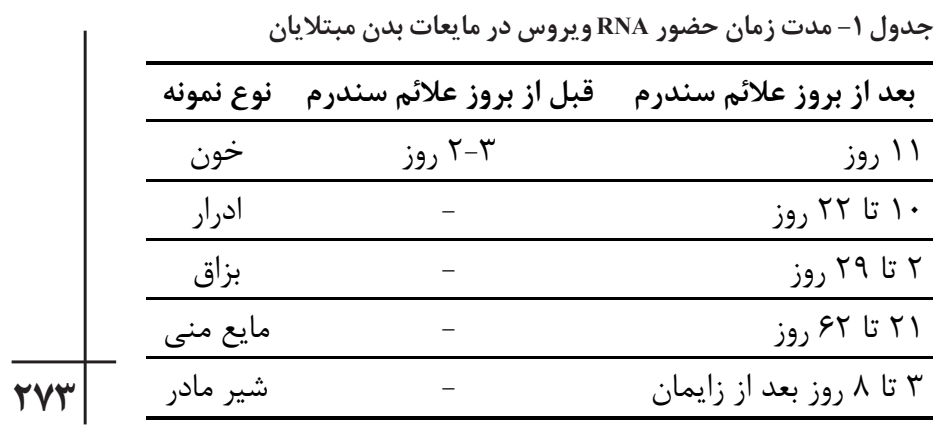

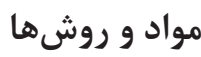

مقاله حاضر يك مقاله مرورى بوده كه از جستجو در منابع

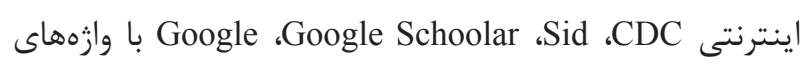
كليدى ويروس زيكا، پُشه آئدس، پيشكَيرى و درمان در سال

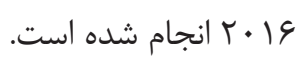

\section{يافتهها}

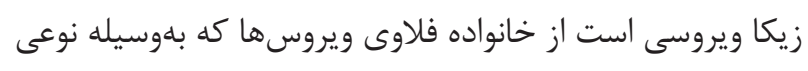

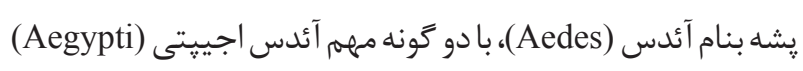

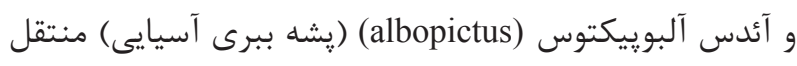

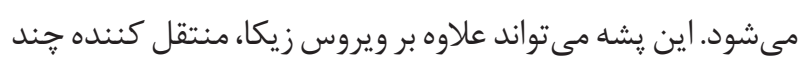
بيمارى ويروسى ديخر مانند تب زرد (Sylvatic yellow fever)، تب دنكى (Dengue)، جيكن گَونيا (Chikungunya) هم باشد.

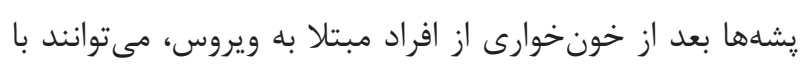
نيش خود اين ويروس را به افراد ديكر منتقل نمايند (Y). سازمان

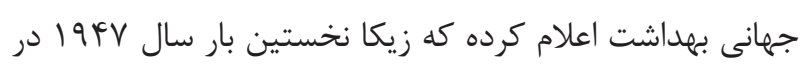

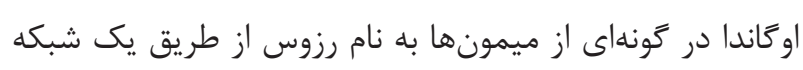
نظارت بر تب زرد شناسايى شد و براى اولين بار در انسان به سال

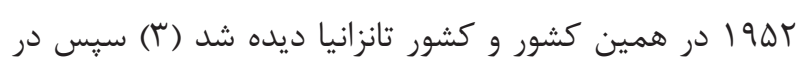
آسياى جنوب شرقى كزارش شد (Y). در حال حاضر برزيل ميزبان

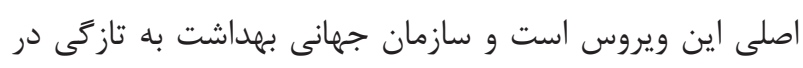
مورد شيوع اين ويروس هشدار داده است (؟).

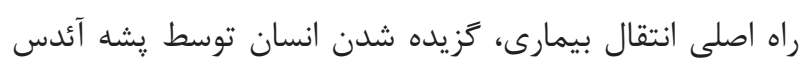

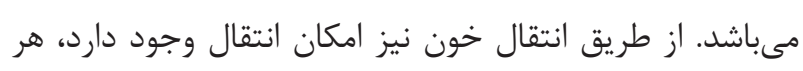

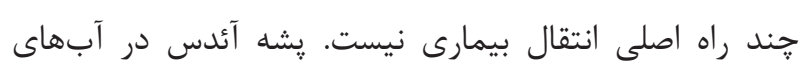

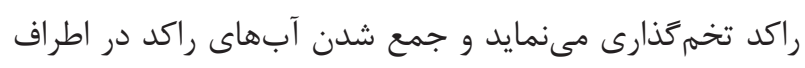

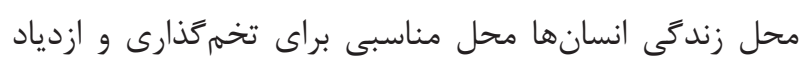
مىباشد (T). به كفته رئيس مركز مديريت بيمارىهاى واگير وزارت بهداشت

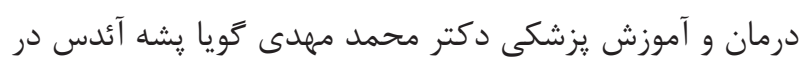

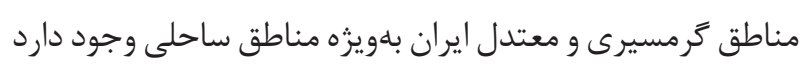

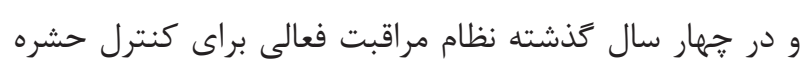

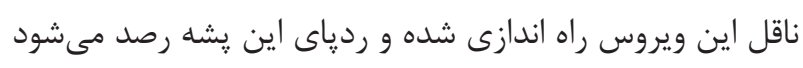

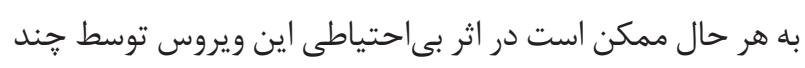


ه- اتر شما داروى ديكرى مصرف مى كنيد حتماً با يزشكتان

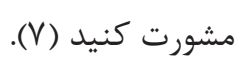

\section{عوارض بيمارى}

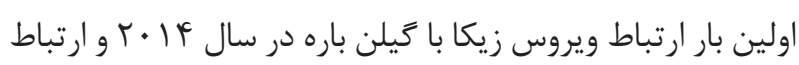

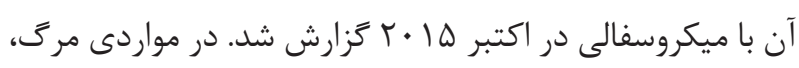

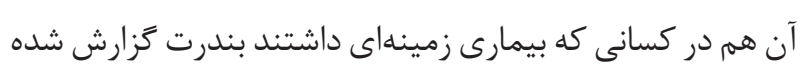

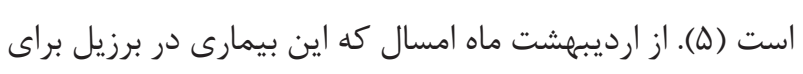

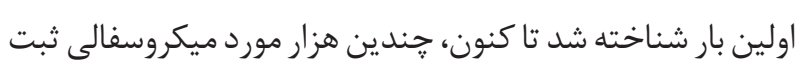

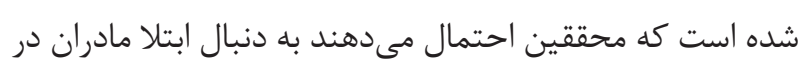

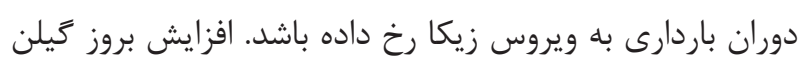

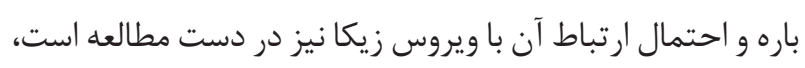
اما در صورت اثبات مىتواند بسيار نغران كننده باشند. سازمان

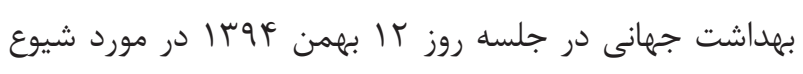

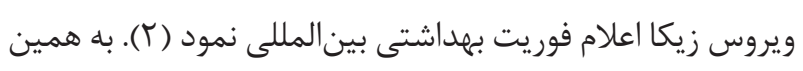

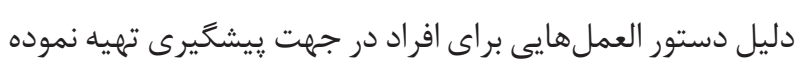
است كه به شرح ذيل مىباشد.

دستورالعمل مراقبت سلامتى براى زنان در سنين بارورى براى

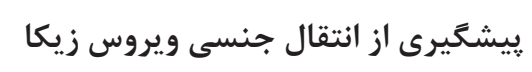

- در مورد شركاى جنسى و مسافرتهاى اخير از زنان باردار

$$
\text { يرسيده شود. }
$$

- توصيه به تعويق انداختن سفر به مناطق شايع ويروس زيكا

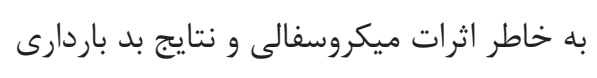

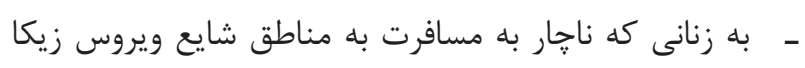

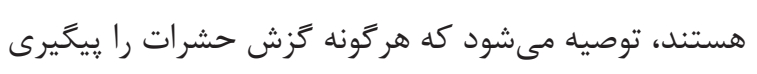

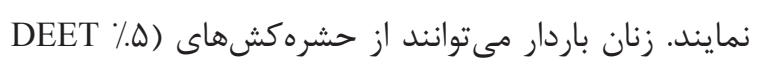
N,N-Diethyl-m-toluamide

$$
\text { ايمن هستند. }
$$

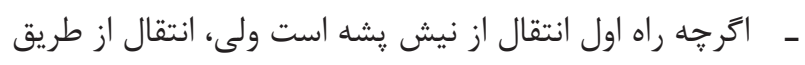

$$
\text { تماس جنسى نيز اتفاق مىافتد. }
$$

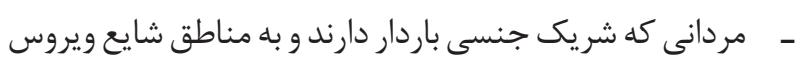

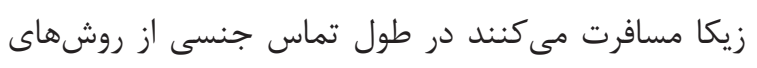

$$
\text { مكانيكى استفاده كنند. }
$$

از طريق تماسهاى مراقبين با مايعات بدن مبتلايان بهويزه

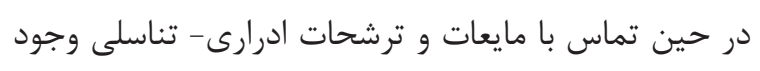
دارد (؟).

تشخيص - بيمارى با تشخيص RNA ويروس زيكا به روش واكنش زنجيرهاى يليمراز (RT-PCR) Polymerase chain reaction در نمونه سرم و ادرار يا وجود آنتى بادى IgM ويروس با تيتر بالاتر از أ محرز مى شود.

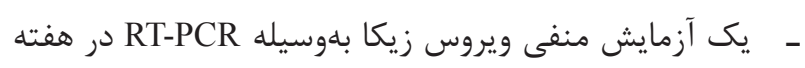
اول بيمارى هميشه عفونت را رد نمى كند.

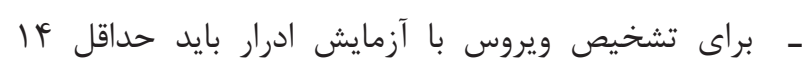

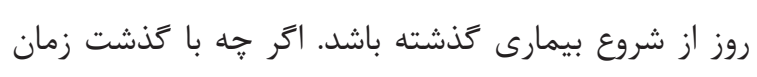
ويرمى كاهش مى يابد و تشخيص سخت مىشود، آزمايشات سرولوزيك بايد انجام شود. - سنجش سرولوزى آنتى بادى IgM ويزه ويروس زيكا كه عمدتاً در طول يايان هفته اول به وجود مي آيد براى تشخيص نيز بندي بكار مىرود، وليكن يك نتيجه مثبت آنتى بادى IgM هميشه نشان دهنده عفونت ويروس زيكا نيست و مى تواند به دليل

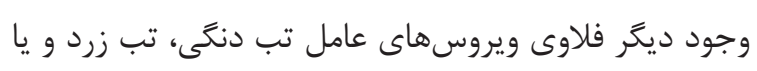
واكسيناسيون قبلى بر ضد فلاوى ويروس وها باشئ ا مىتوان براى تشخيص و تفاوت بين انواع عفونت testing

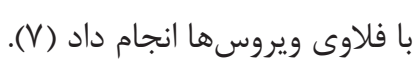
درمان ويروس درمان دارويى يا واكسن خاصى ندارد. درمان علامتى است

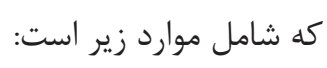
1- استراحت r- نوشيدن مايعات و ييشَّيرى از دهيدراتاسيون

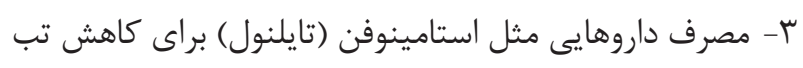
و درد F ع عدم مصرف آسيرين و داروهاى ضد التهابى غير استروئيدى درد براى ييشَيرى از خونريزى (NSAIDS) 
هـ اطلاعرسانى و آكاهسازى كسانى كه قصد سفر به مناطق شايع

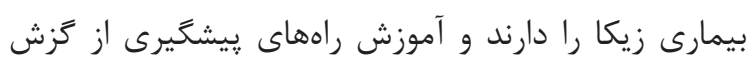

$$
\text { حشره }
$$

צـــ برقرارى نظام مراقبت كَيلن باره و ميكروسفالى بخصوص در

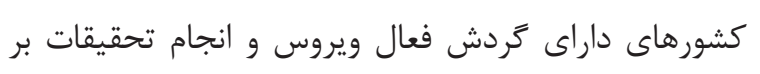

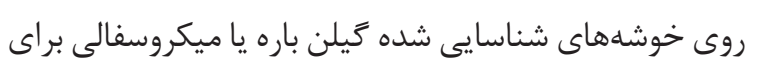
روشن شدن ارتباط عليتى اين خوشهها باويروس زيكا يا عوامل

$$
\text { خطر ديغر }
$$

V- برقرارى و تقويت نظام مراقبت در برابر ويروس زيكا، ارائه تعريف مناسب و راه تشخيص انتخابى براى شناسايى بيماران

$$
\text { در مناطق يرخطر }
$$

^ــ افزايش ظرفيت تشخيصى آزمايشعاه 9ـ همكارى با بهداشت محيط براى سمياشى و كاهش محله لهاى

$$
\text { مناسب براى تخمثزارى حشره }
$$

• 1ـ ضدعفونى كشتىها و هوإيماها بر اساس استانداردهاى تخرى

$$
\text { بين المللى (r). (1) }
$$

\section{بحث و نتيجه}

با توجه به مواردى كه در مقاله به آنها اشاره شد نظير راههاى

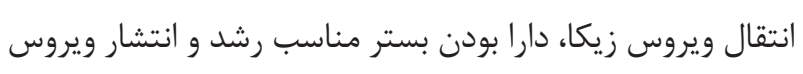

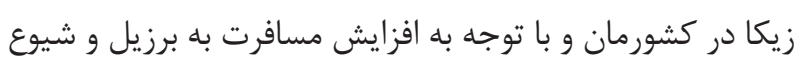
اين ويروس و همغام شدن با جامعه جهانى در ريشخيرى از انتشار

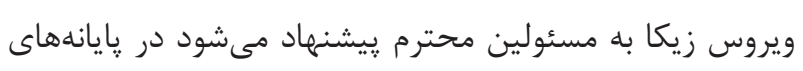

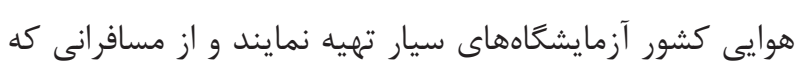

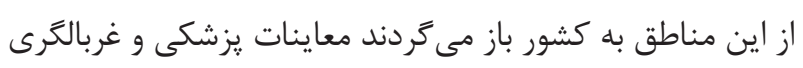

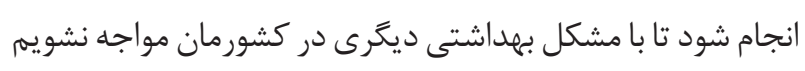

و سخن آخر، هميشه بيشعيرى بهتر از درمان است.

\section{تقدير و تشكر}

بدين وسيله از همكارى و راهنمايى مسئولين و اساتيد دانشكده يرستارى آجا جهت نعارش اين تحقيق تقدير و تشكر مىنمايم.
- توصيه مىشود مردانى كه به ويروس زيكا مبتلا شدهاند از تماس جنسى بدون روشهاى مكانيكى حداقل براى 9 ماه بعد از شروع بيمارى برهيز نمايند.

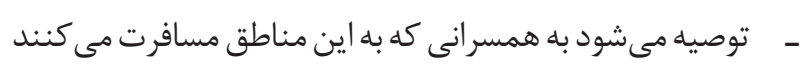

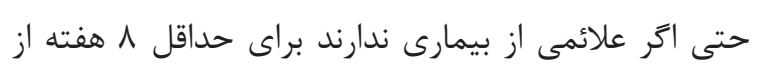
روش هاى مكانيكى استفاده نمايند.

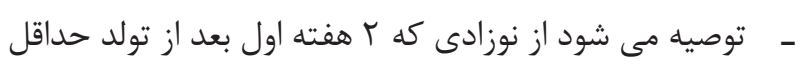

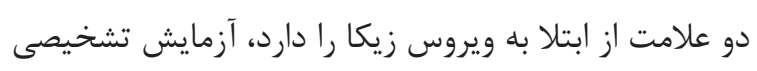
كرفته شود. - همه افرادى كه به مناطق شايع ويروس زيكا مسافرت مى كنند،

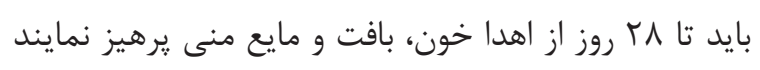

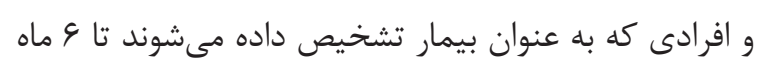
نبايد خون، بافت و مايع منى اهدا نمايند (م).

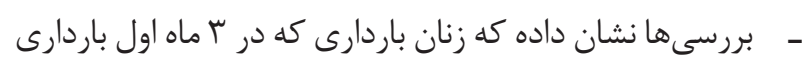

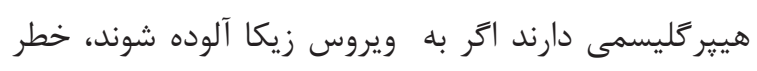

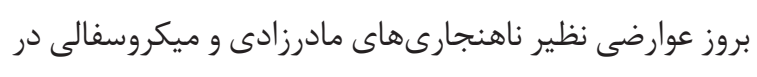

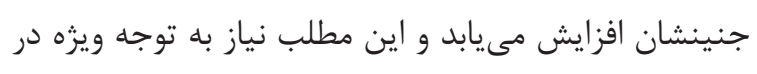

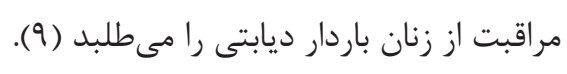

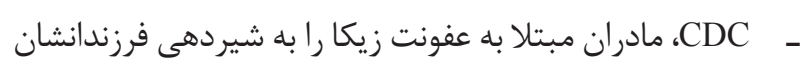
و ترك مناطق شايع بيمارى تشويق مى كند ( •). براى تشخيص نقص در جنين زنان باردار دستورالعملى در

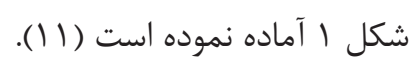
راهكارهاى پِيشنهادى براى كاهش تهديد زيكا به قرار زير

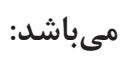
اـ بهترين راه يِيشَيرى، يرهيز از در معرض ويروس قرار كرفتن r- توصيه به تعويق انداختن سفر براى خانمهاى باردار به مناطق شايع ويروس زيكا rــ توجه به كزش حشرات در مناطق شايع ويروس زيكا

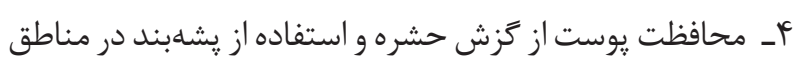
شايع ويروس زيكا (1). 


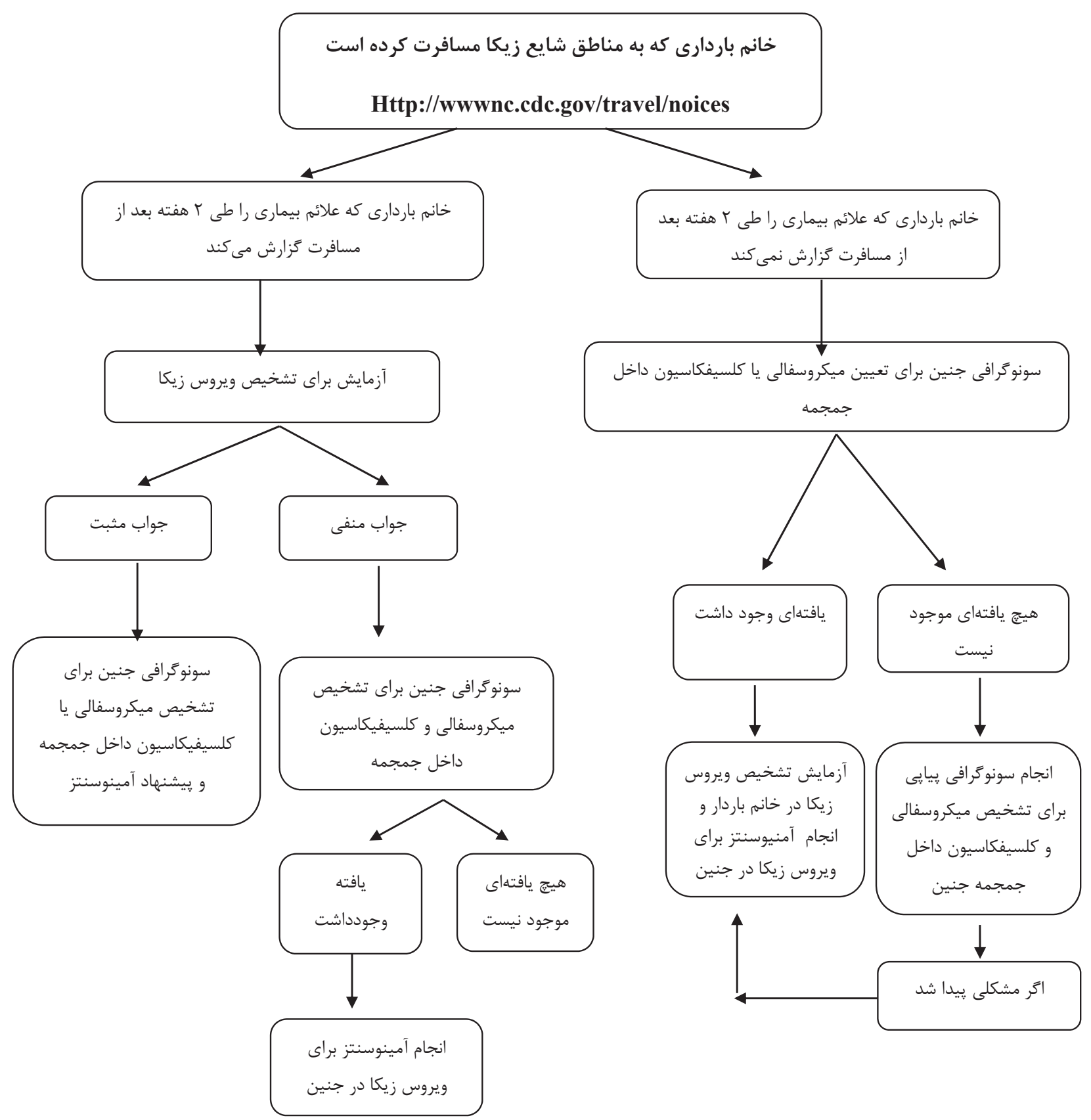

نمودار ا- دستور العمل CDC براى تشخيص نقص در جنين زنان باردار

\section{References}

1- Ghods A. Zika Virus and At the same time fears the spread of disease onset Olympics Rio 20162016 [updated 2016; cited 2016]. Available from: http://www.zoomit.ir/2016/5/16/130721/ zika-infection-olympics-rio-2016.

2- Public Relations of Iran University of Medical Sciences. Zika virus is transmitted to people by the bite of infected mosquitoes in tropical areas is 2016 [updated 2016; cited 2016]. Available from: http://www.behdasht.gov.ir/news/.

3- World Health Organization. Zika virus, Fact sheet 2016 [updated 2016; cited 2016]. Available from: http:/www.who.int/ mediacentre/factsheets/zika/en.

4- Drodeian A. Gain to Iran Zika. Iranews paper. 2016.

5- European Centre for Disease Prevention and Control. Zika virus disease epidemic: potential association with microcephaly and Guillan-Barre syndrome. Stockholm: European Centre for Disease Prevention and Control, 2016.

6- Moreira J, Lamas CC, Siqueira A. Sexual Transmission of Zika Virus: Implications for Clinical Care and Public Health Policy. 
Clin Infect Dis. 2016;63(1):141-2. DOI: 10.1093/cid/ciw211 PMID: 27048746

7- Key messages - Zika virus disease 2017 [updated 2017; cited 2016]. Available from: http://www.cdc.gov/zika/pdfs/zika-keymessages.pdf.

8- Public Health — Seattle \& King County, Protecting and improving the health and well-being of King County, Guidelines for Health Care Providers Caring for Women of Reproductive Age with Zika Virus Exposure and for Prevention of Sexual Transmission of Zika Virus 2016 [updated 2017; cited 2016]. Available from: www. kingcounty.gov/health.

9- Nielsen KK, Bygbjerg IC. Zika virus and hyperglycaemia in pregnancy. Lancet. 2016;387(10030):1812. DOI: 10.1016/S01406736(16)30254-9 PMID: 27103128

10- Fleming-Dutra KE, Nelson JM, Fischer M, Staples JE, Karwowski MP, Mead P, et al. Update: Interim Guidelines for Health Care Providers Caring for Infants and Children with Possible Zika Virus Infection--United States, February 2016. MMWR Morb Mortal Wkly Rep. 2016;65(7):182-7. DOI: 10.15585/mmwr.mm6507e1 PMID: 26914500

11- American College of Obstetricians and Gynecologists. Practice advisory: interim guidance for care of obstetric patients during a zika virus outbreak. Washington: ACOG, 2016. 


\title{
Zika Virus
}

*Soltannezhad. $\mathrm{F}^{1}$

\begin{abstract}
Introduction: According to Zika virus outbreaks in 47 countries and due to the risk of outbreaks in Iran as a result of travel to Brazil Rio de Janeiro 2016 Olympics, which is a common area for Aedes mosquitoes, Zika virus familiarity and introduction is important.
\end{abstract}

Objective: This study aimed at increasing familiarity with the Zika virus.

Materials and Methods: This paper is a review article that includes papers available on Google, CDC, Sid, Google Scholar (2016).

Results: Since the Zika virus emergency was introduced by the World Health Organization and given the importance of this issue, this paper aimed to increase familiarity with the virus, disease, symptoms, diagnosis, treatment and prevention strategies, and to provide recommendations for pregnant females.

Discussion and Conclusion: Due to transmission of the Zika virus and the suitability of our country for the spread of the virus, due to travel to common areas, screening and prevention of the spread of the virus is of great importance.

Keywords: Guillain Barre Syndrome, Prevention strategy, Microcephaly, Zika virus. 